\title{
Stable Organic-Inorganic Hybrid Bismuth-Halide Monocrystalline Compounds With Adjustable Optoelectronic Properties
}

\section{Xinru Hu}

Guilin University of Technology

Jilin Wang ( $\nabla_{\text {jilinwang@glut.edu.cn ) }}$

Guilin University of Technology

Jian He

Guilin University of Technology

Guoyuan Zheng

Guilin University of Technology

Disheng Yao

Guilin University of Technology

Shuyi Mo

Guilin University of Technology

Nan Tian

Guilin University of Technology

Bing Zhou

Guilin University of Technology

Fei Long

Guilin University of Technology

\section{Research Article}

Keywords: Single crystal structure, Organic-inorganic hybrid, Bismuth ( $(\mathbb{Z})$ based hybrid compound, Hirshfeld surface analysis, Optical property and stability

Posted Date: August 6th, 2021

DOl: https://doi.org/10.21203/rs.3.rs-746969/v1

License: (c) (1) This work is licensed under a Creative Commons Attribution 4.0 International License.

Read Full License 


\section{Abstract}

Two kinds of novel organic-inorganic bismuth-halide hybrid monocrystalline compounds $\left(\mathrm{C}_{6} \mathrm{H}_{5} \mathrm{CH}_{2} \mathrm{NH}_{3}\right)_{2} \mathrm{BiCl}_{5}$ and $\left(\mathrm{C}_{6} \mathrm{H}_{5} \mathrm{CH}_{2} \mathrm{NH}_{3}\right) \mathrm{Bil}_{4}$ were synthesized and characterized. The crystal structure, intermolecular interaction, morphology, chemical groups and bonds, optical and thermal stability of the samples were systematically investigated through single crystal X-ray diffraction, Hirshfeld surface analysis, SEM, FTIR, TG and UV-vis diffuse reflectance spectra. The results indicated that $\left(\mathrm{C}_{6} \mathrm{H}_{5} \mathrm{CH}_{2} \mathrm{NH}_{3}\right)_{2} \mathrm{BiCl}_{5}$ and $\left(\mathrm{C}_{6} \mathrm{H}_{5} \mathrm{CH}_{2} \mathrm{NH}_{3}\right) \mathrm{Bil}_{4}$ crystals displayed a monoclinic system with the space group $\mathrm{P} 21 / \mathrm{c}$ and $\mathrm{P} 21 / \mathrm{n}$ at room temperature, respectively. These materials showed strong absorption in the ultraviolet and visible light regions, resulting in very low $E_{g}$, which could be continuously adjustable from $1.67 \mathrm{eV}$ to $3.21 \mathrm{eV}$ by changing the halogen ratio. In addition, these hybrid materials also exhibited good thermal stability. The decomposition temperature of $\left(\mathrm{C}_{6} \mathrm{H}_{5} \mathrm{CH}_{2} \mathrm{NH}_{3}\right)_{2} \mathrm{BiCl}_{5}$ and $\left(\mathrm{C}_{6} \mathrm{H}_{5} \mathrm{CH}_{2} \mathrm{NH}_{3}\right) \mathrm{Bil}_{4}$ were $260^{\circ} \mathrm{C}$ and $300^{\circ} \mathrm{C}$ respectively. Therefore, these organic-inorganic bismuth-halide hybrid compounds have excellent development potential in the field of solar cell research.

\section{Introduction}

In the past 12 years, organic-inorganic hybrid perovskite materials have achieved remarkable results in solar cells[1-3]. The photoelectric conversion efficiency of perovskite solar cells (PSCs) has soared from $3.8-25.5 \%[4,5]$, which is close to the efficiency of commercialized silicon solar cells[6], and much superior to other photovoltaic technologies. At present, most perovskite materials are based on leadhalide $\left(\mathrm{PbX}_{2}\right)$ compounds as a reactant, which contain a heavy metal element. This is harmful to environment and humans' health[7]. In addition, the instability of lead-based perovskite materials is another huge challenge for commercialization of PSCs[8]. These materials decompose easily under exposure of heat, moisture and oxygen, which increase the risk of lead leakage[9]. Therefore, the replacement of lead with environmental-friendly metals is a key issue for the development of PSCs.

Bismuth-based $\left(\mathrm{Bi}^{3+}\right)$ organic-inorganic hybrid materials have attracted much attention from their optoelectronic properties to device performance. Firstly, $\mathrm{Bi}^{3+}$ and $\mathrm{Pb}^{2+}$ have the same electronic arrangement, small ionic radius gap, and closed electronegativity to form a relatively stable perovskite structure[10]. Furthermore, both the Bi-based perovskite material and the $\mathrm{Pb}$-based perovskite material have adjustable optical bandgaps and simple solution processability[11]. Moreover, Bi-based organicinorganic hybrid materials are more stable than lead-based organic-inorganic hybrid materials[12]. Therefore, the Bi-based perovskite is a promising substitute for $\mathrm{Pb}$-based perovskite materials. However, the large band gap of Bi-based perovskites leads to the weakened photoelectric conversion efficiency of the Bi-based PSCs.

Herein, we propose the synthesis of two kinds of bismuth-based monocrystalline perovskites. The crystal structure, intermolecular interaction, morphology, chemical groups and bonds characterization were 
systematically investigated in detailed. In addition, the optical properties and thermal stability for the $\left(\mathrm{C}_{6} \mathrm{H}_{5} \mathrm{CH}_{2} \mathrm{NH}_{3}\right)_{2} \mathrm{BiCl}_{5}$ and $\left(\mathrm{C}_{6} \mathrm{H}_{5} \mathrm{CH}_{2} \mathrm{NH}_{3}\right) \mathrm{Bil}_{4}$ compounds were also investigated.

\section{Experiments}

\subsection{Compound preparation}

All starting reagents were of analytical grade and used without any further purification. Bismuth (III) oxide $\left(\mathrm{Bi}_{2} \mathrm{O}_{3}\right)$ were purchased from Macklin Chemistry Co. Ltd. Benzylamine (99\%), Hydroiodic acid ( $\left.\mathrm{HI}\right)$ $(w t \%=47 \%)$. Hydrochloric acid $(\mathrm{HCl})(w t \%=36 \%)$ were purchased from Xilong Chemistry Co. Ltd. Diethyl ether and ethanol were obtained from Sinopharm Chemical Reagent Co. Ltd. The $\mathrm{C}_{6} \mathrm{H}_{5} \mathrm{CH}_{2} \mathrm{NH}_{3} \mathrm{X}(\mathrm{X}=\mathrm{Cl}, \mathrm{I})$ salts were obtained by the reaction of benzylamine and $\mathrm{HX}$ in an ice bath with continuous stirring for 2 hours. The mixed solution was placed in an oven and dried at $60^{\circ} \mathrm{C}$ for 12 hours. In the next step, the solid product was washed several times with ether and ethanol. Finally, the $\mathrm{C}_{6} \mathrm{H}_{5} \mathrm{CH}_{2} \mathrm{NH}_{3} \mathrm{X}$ was dried in a vacuum at $60^{\circ} \mathrm{C}$ for $12 \mathrm{~h}$.

\subsubsection{Synthesis of $\left(\mathrm{C}_{6} \mathrm{H}_{5} \mathrm{CH}_{2} \mathrm{NH}_{3}\right)_{2} \mathrm{BiCl}_{5}$}

$\mathrm{Bi}_{2} \mathrm{O}_{3}(2330 \mathrm{mg}, 5 \mathrm{mmol})$ and $\mathrm{C}_{6} \mathrm{H}_{5} \mathrm{CH}_{2} \mathrm{NH}_{3} \mathrm{Cl}(718 \mathrm{mg}, 5 \mathrm{mmol})$ were dissolved in $\mathrm{HCl}(5 \mathrm{~mL})$ and DMF (2 $\mathrm{mL}$ ), and the solution was stirred at room temperature for $30 \mathrm{~min}$. The white single crystals were obtained by evaporating the mixed solution in an environment of $60^{\circ} \mathrm{C}$ for 7 days.2.1.2. Synthesis of $\left(\mathrm{C}_{6} \mathrm{H}_{5} \mathrm{CH}_{2} \mathrm{NH}_{3}\right) \mathrm{Bil}_{4}$

$\mathrm{Bi}_{2} \mathrm{O}_{3}(2330 \mathrm{mg}, 5 \mathrm{mmol})$ and $\mathrm{C}_{6} \mathrm{H}_{5} \mathrm{CH}_{2} \mathrm{NH}_{3} \mathrm{I}(1175 \mathrm{mg}, 5 \mathrm{mmol})$ were dissolved in $\mathrm{HI}(10 \mathrm{~mL})$, and the solution was stirred at room temperature for $30 \mathrm{~min}$. The solution was placed in an oven at $100^{\circ} \mathrm{C}$ for 10 hours and red crystals were formed.

\section{Results And Discussion}

\subsection{Morphology and crystal structure}

Figure 1 $\left(a_{1}\right)-\left(b_{1}\right)$ and Fig. 1 $\left(a_{2}\right)-\left(b_{2}\right)$ were the digital photographs and SEM images of the $\left(\mathrm{C}_{6} \mathrm{H}_{5} \mathrm{CH}_{2} \mathrm{NH}_{3}\right)_{2} \mathrm{BiCl}_{5}$ and $\left(\mathrm{C}_{6} \mathrm{H}_{5} \mathrm{CH}_{2} \mathrm{NH}_{3}\right) \mathrm{Bil}_{4}$ single crystals, respectively. The $\left(\mathrm{C}_{6} \mathrm{H}_{5} \mathrm{CH}_{2} \mathrm{NH}_{3}\right)_{2} \mathrm{BiCl}_{5}$ possesses granular shape, while $\left(\mathrm{C}_{6} \mathrm{H}_{5} \mathrm{CH}_{2} \mathrm{NH}_{3}\right) \mathrm{Bil}_{4}$ showed simple prismatic shape. In order to analyze the crystal structure of the single crystal, single crystal diffraction and powder X-ray diffraction (PXRD) were carried out at room temperature. The crystal structures of single crystals were shown in Fig. $\mathbf{1}\left(\mathrm{a}_{3}\right)$ $\left(b_{3}\right)$. At the same time, the single crystal $\mathrm{X}$-ray diffraction data of $\left(\mathrm{C}_{6} \mathrm{H}_{5} \mathrm{CH}_{2} \mathrm{NH}_{3}\right)_{2} \mathrm{BiCl}_{5}$ and $\left(\mathrm{C}_{6} \mathrm{H}_{5} \mathrm{CH}_{2} \mathrm{NH}_{3}\right) \mathrm{Bil}_{4}$ were summarized in Table 1. Owing to different coordinate axes chosen, the $\left(\mathrm{C}_{6} \mathrm{H}_{5} \mathrm{CH}_{2} \mathrm{NH}_{3}\right)_{2} \mathrm{BiCl}_{5}$ crystals belongs to the monoclinic system and P21/c space group, while the $\left(\mathrm{C}_{6} \mathrm{H}_{5} \mathrm{CH}_{2} \mathrm{NH}_{3}\right) \mathrm{Bil}_{4}$ crystals the monoclinic system and P21/n space group. The crystal structures of the 
anisotropic displacement parameters and other structural information have been deposited with the Cambridge Crystallographic Data Centre under the registration number CCDC 1886951, 1883198, respectively. 
Table 1

Crystal data and structure refinement for $\left(\mathrm{C}_{6} \mathrm{H}_{5} \mathrm{CH}_{2} \mathrm{NH}_{3}\right)_{\mathrm{a}} \mathrm{Bi}_{\mathrm{b}} \mathrm{X}_{\mathrm{c}}$

\begin{tabular}{|c|c|c|}
\hline Empirical formula & $\left(\mathrm{C}_{6} \mathrm{H}_{5} \mathrm{CH}_{2} \mathrm{NH}_{3}\right)_{2} \mathrm{BiCl}_{5}$ & $\left(\mathrm{C}_{6} \mathrm{H}_{5} \mathrm{CH}_{2} \mathrm{NH}_{3}\right) \mathrm{Bil}_{4}$ \\
\hline Formula weight ( $\left.\mathrm{g} \mathrm{mol}^{-1}\right)$ & 602.55 & 1649.48 \\
\hline Crystal system & monoclinic & monoclinic \\
\hline Space group & $\mathrm{P} 2{ }_{1} / \mathrm{c}$ & $\mathrm{P} 2{ }_{1} / \mathrm{n}$ \\
\hline$a\left(^{\circ}\right)$ & 90 & 90 \\
\hline$\beta\left(^{\circ}\right)$ & 97.195(3) & $90.455(4)$ \\
\hline$Y\left(^{\circ}\right)$ & 90 & 90 \\
\hline $\mathrm{a}(\AA)$ & $13.5528(4)$ & $12.4166(6)$ \\
\hline$b(\AA)$ & $12.8311(3)$ & $7.8330(4)$ \\
\hline$c(\AA)$ & $12.1296(3)$ & $15.9264(7)$ \\
\hline Volume $\left(\AA^{3}\right)$ & $2092.68(9)$ & $1548.95(12)$ \\
\hline $\mathbf{Z}$ & 4 & 2 \\
\hline Density $\left(\mathrm{g} \mathrm{cm}^{-3}\right)$ & 1.912 & 3.537 \\
\hline Diffractometer/scan & Agilent G8910A CCD & Agilent G8910A CCD \\
\hline Radiation, $\lambda(\AA)$, & 0.71073 & 0.71073 \\
\hline Monochromator $\theta$ range $\left(^{\circ}\right)$ & 6.772 to 58.546 & 6.564 to 58.13 \\
\hline Unique reflections & 15133 & 11205 \\
\hline$F\left(\begin{array}{lll}0 & 0 & 0\end{array}\right)$ & 1144.0 & 1416.0 \\
\hline Index ranges & $\begin{array}{l}-18 \leq h \leq 17,-17 \leq k \leq 15,-16 \leq 1 \\
\leq 14\end{array}$ & $\begin{array}{l}-15 \leq h \leq 16,-10 \leq k \leq 10,-15 \leq l \\
\leq 20\end{array}$ \\
\hline GOF on $\mathrm{F}^{2}$ & 1.036 & 1.138 \\
\hline Absorption correction & Spherical harmonics & Spherical harmonics \\
\hline Data/restraints/parameters & $5052 / 0 / 201$ & $3672 / 0 / 120$ \\
\hline Final R indexes $[\mid>2 \sigma(I)]$ & $R_{1}=0.0341, w R_{2}=0.0664$ & $\mathrm{R}_{1}=0.0379, \mathrm{wR}_{2}=0.0790$ \\
\hline Final $R$ indexes (all data) & $R_{1}=0.0591, w R_{2}=0.0777$ & $R_{1}=0.0487, w R_{2}=0.0849$ \\
\hline $\operatorname{Min} / \max \left(q / e \AA^{-3}\right)$ & $1.44 /-1.34$ & $1.89 /-1.07$ \\
\hline
\end{tabular}


$\left(\mathrm{C}_{6} \mathrm{H}_{5} \mathrm{CH}_{2} \mathrm{NH}_{3}\right)_{2} \mathrm{BiCl}_{5}$ presented typical two-dimensional (2D) structure. The basic structural unit of $\left(\mathrm{C}_{6} \mathrm{H}_{5} \mathrm{CH}_{2} \mathrm{NH}_{3}\right)_{2} \mathrm{BiCl}_{5}$ compound consisted of benzylammonium cation and corner-sharing $\left[\mathrm{BiCl}_{6}\right]$ octahedra. Each $\mathrm{Bi}^{3+}$ in the structure was surrounded by six halogen anions $\mathrm{Cl}^{-}$to form an inorganic octahedral structure. The octahedrons were connected by sharing two halogen anions $\mathrm{Cl}^{-}$.

$\left[\mathrm{C}_{6} \mathrm{H}_{5} \mathrm{CH}_{2} \mathrm{NH}_{3}\right]^{+}$cations occupyed the gaps of the octahedral, and each inorganic layer $\left[\mathrm{BiCl}_{6}\right]^{-}$connected two adjacent organic layers $\left[\mathrm{C}_{6} \mathrm{H}_{5} \mathrm{CH}_{2} \mathrm{NH}_{3}\right]^{+}$to form an alternating organic-inorganic hybrid structure. The organic group and the inorganic octahedron were connected by unequal $\mathrm{N}-\mathrm{H} \ldots \mathrm{Cl}$ hydrogen bonds, combined with weak van der Waals interactions to form a two-dimensional perovskite structure.

While $\left(\mathrm{C}_{6} \mathrm{H}_{5} \mathrm{CH}_{2} \mathrm{NH}_{3}\right) \mathrm{Bil}_{4}$ displayed typical one-dimensional (1D) structure which consisted of $\left[\mathrm{C}_{6} \mathrm{H}_{5} \mathrm{CH}_{2} \mathrm{NH}_{3}\right]^{+}$cations and infinite linear anionic chains $\left[\mathrm{Bi}_{6}\right]^{-}$. In the crystal structure, each $\mathrm{Bi}^{3+}$ is surrounded by six halogen anions $\mathrm{I}^{-}$to form an inorganic octahedral structure. And the adjacent octahedrons were connected by sharing two anion $\mathrm{I}^{-}$to form a one-dimensional chain. The organic group $\left[\mathrm{C}_{6} \mathrm{H}_{5} \mathrm{CH}_{2} \mathrm{NH}_{3}\right]^{+}$occupied the octahedral gap which was connected with the inorganic octahedral structure through the $\mathrm{N}-\mathrm{H} \cdots$ I hydrogen bond to form an organic-inorganic hybrid structure.

To investigate the purity of two types of single crystals, the PXRD were performed as shown in Fig. 2( $\left.\mathbf{a}_{1}\right)$ $\left(b_{2}\right)$. It could be seen from the figure that the experimental test pattern was roughly consistent with the theoretical simulation pattern which indicated the reliability of refined single crystal structures and purity phase of those crystals.

\subsection{Hirshfeld surface analysis}

To research the various interactions that lead to the crystal structure in detail, Hirshfeld surfaces[13] and fingerprint plots were generated for the $\left(\mathrm{C}_{6} \mathrm{H}_{5} \mathrm{CH}_{2} \mathrm{NH}_{3}\right)_{\mathrm{a}} \mathrm{Bi}_{\mathrm{b}} \mathrm{X}_{\mathrm{c}}$ compound based on the crystallographic information file (CIF) using CrystalExplorer[14]. Hirshfeld surfaces enable the visualization of intermolecular interactions with different colours and colour intensity representing short or long contacts and indicating the relative strength of the interactions.

It was a significant advance in understanding the crystal packing behavior[15] which using the 2Dfingerprint plots and shape index to analysis the intermolecular interactions. The distance of the threedimensional (3D) molecular Hirshfeld surfaces from surface to the nearest nucleus inside the surface was defined ' $d$ ', and the distance from surface to the nearest nucleus outside the surface was defined ' $d_{e}^{\prime}[16]$. The normalized contact distance $\left(d_{\text {norm }}\right)$ is given by:

$d_{\text {nom }}=\frac{d_{i}-r_{l}^{v d w}}{r_{l}^{v d w}}+\frac{d_{e}-r_{e}^{v d w}}{r_{e}^{v d w}}$

' $r_{i}^{v d w '}$ and ' $r_{e}^{v d w '}$ were defined the van der Waals radii of the appropriate atoms, respectively. Graphical plots of the molecular Hirshfeld surfaces mapped with $d_{\text {norm }}$ employ the red-white-blue colour scheme where red area represents the strongest contact, blue area indicates weaker contact. 
The ' $d_{i}^{\prime}$ ', ' $d_{e}^{\prime}$, ' $d_{\text {norm }}$ ', shape index, curvedness curves mapping on Hirshfeld surface of $\left(\mathrm{C}_{6} \mathrm{H}_{5} \mathrm{CH}_{2} \mathrm{NH}_{3}\right)_{2} \mathrm{BiCl}_{5}$ were shown in the Fig. 3. The fixed color scale in Fig. $3 a_{1}$-a $_{5}$ were $0.901 \AA$ (red) $~ 2.879 \AA$ (blue), 0.903 $\AA ̊ 2.972 \AA,-0.416 \AA \sim 1.558 \AA,-1.000 \AA \sim 1.000 \AA$, and $-4.000 \AA \sim 0.400 \AA$ respectively. The corresponding $2 \mathrm{D}$ fingerprint plot of $\left(\mathrm{C}_{6} \mathrm{H}_{5} \mathrm{CH}_{2} \mathrm{NH}_{3}\right)_{2} \mathrm{BiCl}_{5}$ was as shown in Figure $\mathrm{S} 1$. Globally, the $\mathrm{H} \cdots \mathrm{Cl} / \mathrm{Cl} \cdots \mathrm{H}$ intermolecular interactions had the largest contribution to the Hirshfeld surface, with percentage contributions of $46.2 \%(19.4 \%+26.8 \%)$. Owing to the molecular surface had large amount of hydrogen, the second most abundant interactions contribution was from $\mathrm{H} \cdots \mathrm{H}$ contacts with percentage of $34.8 \%$. The remaining $\mathrm{C} \cdots \mathrm{Cl} / \mathrm{Cl} \cdots \mathrm{C}, \mathrm{H} \cdots \mathrm{C} / \mathrm{C} \cdots \mathrm{H}, \mathrm{Cl} \cdots \mathrm{Cl}, \mathrm{Bi} \cdots \mathrm{Cl} / \mathrm{Cl} \cdots \mathrm{Bi}, \mathrm{C} \cdots \mathrm{C}$ intermolecular contacts of the Hirshfeld surface only contributes $0.2 \%, 12.9 \%, 1.6 \%, 3.4 \%, 0.8 \%$ respectively.

The ' $d_{i}^{\prime}$, ' $d_{e}$ ', ' $d_{\text {norm }}$ ', shape index and curvedness curves surfaces of compound $\left(\mathrm{C}_{6} \mathrm{H}_{5} \mathrm{CH}_{2} \mathrm{NH}_{3}\right) \mathrm{Bil}_{4}$ were shown in the Fig. 4, the fixed color scale of 3D mapped surfaces were between $1.000 \AA$ (red) 2.940 (blue), $0.946 \AA ̊ 22.823 \AA,-0.356 \AA ̊ 1.016 \AA,-1.000 \AA ̊ 1.000 \AA$, and $-4.000 \AA \sim 4.000 \AA$ respectively. Figure S2 provide us information about intermolecular interactions of 2D-fingerprint plots. The decomposition of the fingerprint plots show that $\mathrm{H} \cdots \mathrm{l} / \mathrm{I} \cdots \mathrm{H}$ contacts comprise $64 \%$ of the total Hirshfeld surface area for the molecule of $\left(\mathrm{C}_{6} \mathrm{H}_{5} \mathrm{CH}_{2} \mathrm{NH}_{3}\right) \mathrm{Bil}_{4}$ which confirms significant of these interactions on structural stability. Furthermore, the proportion of $\mathrm{H} \cdots \mathrm{H}$ interactions to the tune of $12.2 \%$ in Hirshfeld surfaces of $\left(\mathrm{C}_{6} \mathrm{H}_{5} \mathrm{CH}_{2} \mathrm{NH}_{3}\right) \mathrm{Bil}_{4}$ indicated that these contacts are the second most significant interaction. Apart from these above, the $\mathrm{C} \cdots \mathrm{H} / \mathrm{H} \cdots \mathrm{C}, \mathrm{C} \cdots \mathrm{C},|\cdots \mathrm{C} / \mathrm{C} \cdots|,|\cdots|, \mathrm{Bi} \cdots \mathrm{H}, \mathrm{Bi} \cdots \mathrm{|} / \mathrm{|} \cdots \mathrm{Bi}$ of the Hirshfeld surface only contributes $6.5 \%, 2.7 \%, 0.6 \%, 4.7 \%, 0.1 \%, 9.2 \%$ respectively.

According to the parameter analysis of the ' $d_{i}^{\prime}$, ' $d_{e}^{\prime},{ }^{\prime}, d_{n o r m}$ ', shape index and curvedness curves of $\left(\mathrm{C}_{6} \mathrm{H}_{5} \mathrm{CH}_{2} \mathrm{NH}_{3}\right)_{2} \mathrm{BiCl}_{5}$ and $\left(\mathrm{C}_{6} \mathrm{H}_{5} \mathrm{CH}_{2} \mathrm{NH}_{3}\right) \mathrm{Bil}_{4}$, the ratios of the bonds and the interaction ratios between the elements are different because of the difference in halogens.

\subsection{FT-IR Spectra study}

In order to understand information about the organic group and inorganic framework of the compound $\left(\mathrm{C}_{6} \mathrm{H}_{5} \mathrm{CH}_{2} \mathrm{NH}_{3}\right)_{\mathrm{a}} \mathrm{Bi}_{\mathrm{b}} \mathrm{X}_{\mathrm{c}}$ in more detail, FT-IR spectroscopy were performed (Fig. 5). And the detailed assignments of vibrational models were listed in Table 2. Obviously, the peaks between $500-3500 \mathrm{~cm}^{-1}$ belong to the benzylamine ring, and those peaks below $500 \mathrm{~cm}^{-1}$ belong to the peak of $(\mathrm{Bi}-\mathrm{X})(\mathrm{X}=\mathrm{Cl}, \mathrm{I})$ [17]. The asymmetric and symmetric stretching bands of $\mathrm{NH}_{3}{ }^{+}$were usuallylocated at 3330 and 3080 $\mathrm{cm}^{-1}$ [18], respectively. In $\left(\mathrm{C}_{6} \mathrm{H}_{5} \mathrm{CH}_{2} \mathrm{NH}_{3}\right)_{\mathrm{a}} \mathrm{Bi}_{\mathrm{b}} \mathrm{X}_{\mathrm{c}}$, the $\mathrm{NH}_{3}{ }^{+}$group interacts with the halide atoms through $\mathrm{N}$ $\mathrm{H} \cdots \mathrm{X}$ hydrogen bonds. As seen from Table 2, the $\delta_{\text {asym }}\left(\mathrm{NH}_{3}\right)$ and $\delta_{\text {sym }}\left(\mathrm{NH}_{3}\right)$ modes are coupled with the $\mathrm{C}-\mathrm{C}$ ring stretching mode. The $\mathrm{CH}_{2}$ asymmetric and symmetric stretching modes are observed at 2849 to $2856 \mathrm{~cm}^{-1}$ and at $2764 \mathrm{~cm}^{-1}[19]$. 
Table 2

Measured resonance frequencies of vibrational modes and peak assignments for the $\left(\mathrm{C}_{6} \mathrm{H}_{5} \mathrm{CH}_{2} \mathrm{NH}_{3}\right)_{\mathrm{a}} \mathrm{Bi}_{\mathrm{b}} \mathrm{X}_{\mathrm{c}}$

\begin{tabular}{|c|c|c|}
\hline $\begin{array}{l}\left(\mathrm{C}_{6} \mathrm{H}_{5} \mathrm{CH}_{2} \mathrm{NH}_{3}\right)_{2} \mathrm{BiCl}_{5} \\
\text { IR Wavenumbers }\left(\mathrm{cm}^{-1}\right)\end{array}$ & $\begin{array}{l}\left(\mathrm{C}_{6} \mathrm{H}_{5} \mathrm{CH}_{2} \mathrm{NH}_{3}\right) \mathrm{Bil}_{4} \\
\text { IR Wavenumbers }\left(\mathrm{cm}^{-1}\right)\end{array}$ & Peak assignment \\
\hline 3443 & 3443 & $\mathrm{U}_{\text {asym }}\left(\mathrm{NH}_{3}^{+}\right)$ \\
\hline 3117 & 3146 & $\mathrm{U}_{\text {sym }}\left(\mathrm{NH}_{3}^{+}\right)$ \\
\hline 2920 & 2920 & $\mathrm{U}_{\text {asym }}\left(\mathrm{CH}_{3}\right)$ \\
\hline 2849 & 2856 & $\mathrm{U}_{\text {asym }}\left(\mathrm{CH}_{2}\right)$ \\
\hline 2764 & - & $\mathrm{v}_{\mathrm{sym}}\left(\mathrm{CH}_{2}\right)$ \\
\hline 1628 & 1628 & $\delta_{\text {asym }}\left(\mathrm{NH}_{3}\right)+\mathrm{v}(\mathrm{C}-\mathrm{C})$ ring \\
\hline 1551 & 1558 & $\delta_{\text {sym }}\left(\mathrm{NH}_{3}\right)+\mathrm{v}(\mathrm{C}-\mathrm{C})$ ring \\
\hline 1459 & 1445 & $\delta_{\text {sym }}\left(\mathrm{CH}_{3}\right)+\delta_{\text {sym }}\left(\mathrm{CH}_{2}\right)$ \\
\hline 1359 & 1374 & $\mathrm{U}_{\text {asym }}(\mathrm{C}-\mathrm{N})$ \\
\hline 1078 & 1057 & $\beta(C-H)$ \\
\hline- & - & $\beta(C-H)$ \\
\hline 1014 & 923 & $\rho\left(\mathrm{NH}_{3}\right)$ \\
\hline 880 & 845 & $Y(C-H)$ \\
\hline 810 & 781 & $\gamma(C-H)$ \\
\hline 753 & 746 & $u(C-C)+\beta(C-C-C)$ \\
\hline 696 & 690 & $\mathrm{Y}(\mathrm{C}-\mathrm{C}-\mathrm{C})$ \\
\hline 569 & 563 & $\beta(C-C-C)$ \\
\hline 484 & 478 & $\mathrm{U}_{\text {asym }}(\mathrm{Bi}-\mathrm{X})$ \\
\hline
\end{tabular}

\subsection{Thermogravimetric analysis and stability}

To investigate the mass loss behavior of each component of the $\left(\mathrm{C}_{6} \mathrm{H}_{5} \mathrm{CH}_{2} \mathrm{NH}_{3}\right)_{\mathrm{a}} \mathrm{Bi}_{b} \mathrm{X}_{\mathrm{c}}$ single crystal materials in detail, the thermogravimetric curve were obtained from room temperature to $800^{\circ} \mathrm{C}$. As 
Fig. 6a shown, $\left(\mathrm{C}_{6} \mathrm{H}_{5} \mathrm{CH}_{2} \mathrm{NH}_{3}\right)_{2} \mathrm{BiCl}_{5}$ exhibited one thermal events and was stable up to $260^{\circ} \mathrm{C}$, all organic and inorganic compounds decompose completely at $350^{\circ} \mathrm{C}$. And the $\left(\mathrm{C}_{6} \mathrm{H}_{5} \mathrm{CH}_{2} \mathrm{NH}_{3}\right) \mathrm{Bil}_{4}$ is stable up to $300^{\circ} \mathrm{C}$, decomposed completely at $410^{\circ} \mathrm{C}$. In short, different halogens have different stability between Bi$\mathrm{X}$ bonds, resulting in different stability of compounds.

\subsection{Optical property}

To calculate the optical band gap of $\left(\mathrm{C}_{6} \mathrm{H}_{5} \mathrm{CH}_{2} \mathrm{NH}_{3}\right)_{a} \mathrm{Bi}_{\mathrm{b}} \mathrm{X}_{\mathrm{c}}$, UV-Visible absorption spectra were carried out, as shown in Fig. 7. The absorbance as a function of reflectance explained by Kubelka-Munk Eq. [20], the formula is as follows:

$\mathrm{F}(\mathrm{R})=\mathrm{a}=(1-\mathrm{R})^{2} /(2 \mathrm{R})(2)$

where $\mathrm{R}$ represents the value of light reflectivity and a means the optical absorption coefficient.

According to the UV-vis spectrum, it could clearly observe that the absorption edge of $\left(\mathrm{C}_{6} \mathrm{H}_{5} \mathrm{CH}_{2} \mathrm{NH}_{3}\right)_{2} \mathrm{BiCl}_{5},\left(\mathrm{C}_{6} \mathrm{H}_{5} \mathrm{CH}_{2} \mathrm{NH}_{3}\right) \mathrm{Bil}_{4}$ was located at about $440 \mathrm{~nm}, 890 \mathrm{~nm}$ which indicating that the band gap was $3.21 \mathrm{eV}, 1.67 \mathrm{eV}$ respectively. As the ionic radius of $\mathrm{I}^{-}$is larger than that of $\mathrm{Cl}^{-}$, the ultraviolet-visible absorption peak of $\left(\mathrm{C}_{6} \mathrm{H}_{5} \mathrm{CH}_{2} \mathrm{NH}_{3}\right) \mathrm{Bil}_{4}$ is red-shifted compared to $\left(\mathrm{C}_{6} \mathrm{H}_{5} \mathrm{CH}_{2} \mathrm{NH}_{3}\right)_{2} \mathrm{BiCl}_{5}$, resulting in an increase in the light absorption range[21-23]. Therefore, the band gaps of $\left(\mathrm{C}_{6} \mathrm{H}_{5} \mathrm{CH}_{2} \mathrm{NH}_{3}\right) \mathrm{Bil}_{4}$ is smaller than the $\left(\mathrm{C}_{6} \mathrm{H}_{5} \mathrm{CH}_{2} \mathrm{NH}_{3}\right)_{2} \mathrm{BiCl}_{5}$, the light absorption range of $\left(\mathrm{C}_{6} \mathrm{H}_{5} \mathrm{CH}_{2} \mathrm{NH}_{3}\right) \mathrm{Bil}_{4}$ is wider than the $\left(\mathrm{C}_{6} \mathrm{H}_{5} \mathrm{CH}_{2} \mathrm{NH}_{3}\right)_{2} \mathrm{BiCl}_{5}$. In summary, the $\left(\mathrm{C}_{6} \mathrm{H}_{5} \mathrm{CH}_{2} \mathrm{NH}_{3}\right) \mathrm{Bil}_{4}$ have more application potential in light-emitting, Diodes (LEDs), photodetectors, lasers and other fields, compared to the $\left(\mathrm{C}_{6} \mathrm{H}_{5} \mathrm{CH}_{2} \mathrm{NH}_{3}\right)_{2} \mathrm{BiCl}_{5}$.

\section{Conclusions}

Two kinds of novel single crystal materials $\left(\mathrm{C}_{6} \mathrm{H}_{5} \mathrm{CH}_{2} \mathrm{NH}_{3}\right)_{a} \mathrm{Bi}_{\mathrm{b}} \mathrm{X}_{\mathrm{c}}(\mathrm{X}=\mathrm{Cl}$, I) were successfully synthesized by different preparation methods. The $\left(\mathrm{C}_{6} \mathrm{H}_{5} \mathrm{CH}_{2} \mathrm{NH}_{3}\right)_{2} \mathrm{BiCl}_{5}$ and $\left(\mathrm{C}_{6} \mathrm{H}_{5} \mathrm{CH}_{2} \mathrm{NH}_{3}\right) \mathrm{Bil}_{4}$ crystals were demonstrated monoclinic system with the space group P21/c and P21/n at room temperature, respectively. These single crystals show various types of intermolecular interactions such as hydrogen bonding. The band gap values of $\left(\mathrm{C}_{6} \mathrm{H}_{5} \mathrm{CH}_{2} \mathrm{NH}_{3}\right)_{2} \mathrm{BiCl}_{5}$ and $\left(\mathrm{C}_{6} \mathrm{H}_{5} \mathrm{CH}_{2} \mathrm{NH}_{3}\right) \mathrm{Bil}_{4}$ decreased from $3.21 \mathrm{eV}$ to $1.67 \mathrm{eV}$ respectively. Simultaneously, the single crystal materials $\left(\mathrm{C}_{6} \mathrm{H}_{5} \mathrm{CH}_{2} \mathrm{NH}_{3}\right)_{\mathrm{a}} \mathrm{Bi}_{\mathrm{b}} \mathrm{X}_{\mathrm{c}}(\mathrm{X}=\mathrm{Cl}$, I) was provided with high thermal stability which $\left(\mathrm{C}_{6} \mathrm{H}_{5} \mathrm{CH}_{2} \mathrm{NH}_{3}\right)_{2} \mathrm{BiCl}_{5}$ and $\left(\mathrm{C}_{6} \mathrm{H}_{5} \mathrm{CH}_{2} \mathrm{NH}_{3}\right) \mathrm{Bil}_{4}$ could be kept within $260^{\circ} \mathrm{C}$ and $300^{\circ} \mathrm{C}$ without decomposition respectively. In conclusion, the performance of $\left(\mathrm{C}_{6} \mathrm{H}_{5} \mathrm{CH}_{2} \mathrm{NH}_{3}\right)_{\mathrm{a}} \mathrm{Bi}_{\mathrm{b}} \mathrm{X}_{\mathrm{c}}(\mathrm{X}=\mathrm{Cl}$, I) materials indicates its excellent development potential in the field of solar cell research.

\section{Declarations}

\section{Funding}


The authors acknowledge the financial support from National Natural Science Foundation of China (No.51972071), Guangxi Research Foundation for Science and Technology Base and Talent Special (No. AD19245175), Non-ferrous metals and materials processing new technology Ministry of education key laboratory open fund project (No.19AA-14), and Guangxi Distinguished Experts Special Fund (No.2019B06).

\section{Declaration of Competing Interest}

We declare that We have no known competing financial interests or personal relationships that could have appeared to influence the work reported in this paper.

\section{Data availability}

All data generated or analyzed during this study are included in this published article.

\section{Authors' contributions}

All authors contributed to the study conception and design. Xinru Hu, Jilin Wang, Fei Long performed material preparation, data collection, and analysis. Xinru Hu wrote the first draft of the manuscript and all authors commented on previous versions of the manuscript. All authors read and approved the final manuscript.

\section{References}

1. Li X-L, Li Z, Zhang G, Yang G-J (2020) Lead-free perovskite $\left[\mathrm{H}_{3} \mathrm{NC}_{6} \mathrm{H}_{4} \mathrm{NH}_{3}\right] \mathrm{CuBr}_{4}$ with both a bandgap of $1.43 \mathrm{eV}$ and excellent stability. Journal of Materials Chemistry A 8:5484-5488

2. Ji C, Wang P, Wu Z, Sun Z, Li L, Zhang J et al (2018) Inch-Size Single Crystal of a Lead-Free OrganicInorganic Hybrid Perovskite for High-Performance Photodetector. Adv Funct Mater 28:1705467

3. Liu Y, Zhang Y, Yang Z, Ye H, Feng J, Xu Z et al (2018) Multi-inch single-crystalline perovskite membrane for high-detectivity flexible photosensors. Nat Commun 9:5302

4. Kojima A, Teshima K, Shirai Y, Miyasaka T (2009) Organometal halide perovskites as visible-light sensitizers for photovoltaic cells. J Am Chem Soc 131:6050-6051

5. Laboratory NRE, Best Research-Cell Efficiency Chart, https://www.nrel.gov/pv/cell-efficiency.html. NRE Laboratory, Best Research-Cell Efficiency Chart, https://wwwnrelgov/pv/cell-efficiencyhtml

6. Yoshikawa K, Kawasaki H, Yoshida W, Irie T, Konishi K, Nakano K et al (2017) Silicon heterojunction solar cell with interdigitated back contacts for a photoconversion efficiency over $26 \%$. Nature energy $2: 1-8$

7. Ke W, Stoumpos CC, Kanatzidis MG (2019) “Unleaded” perovskites: status quo and future prospects of tin-based perovskite solar cells. Adv Mater 31:1803230

8. Ke W, Kanatzidis MG (2019) Prospects for low-toxicity lead-free perovskite solar cells. Nat Commun 10:1-4 
9. Boyd CC, Cheacharoen R, Leijtens T, McGehee MD (2018) Understanding degradation mechanisms and improving stability of perovskite photovoltaics. Chem Rev 119:3418-3451

10. Wu C, Zhang Q, Liu G, Zhang Z, Wang D, Qu B et al (2020) From Pb to Bi: A Promising Family of PbFree Optoelectronic Materials and Devices. Advanced Energy Materials 10:1902496

11. Kou B, Zhang W, Ji C, Wu Z, Zhang S, Liu X et al (2019) Tunable optical absorption in lead-free perovskite-like hybrids by iodide management. Chem Commun 55:14174-14177

12. Lyu M, Yun J-H, Cai M, Jiao Y, Bernhardt PV, Zhang M et al (2016) Organic-inorganic bismuth (III)based material: A lead-free, air-stable and solution-processable light-absorber beyond organolead perovskites. Nano Research 9:692-702

13. Spackman MA, Jayatilaka D (2009) Hirshfeld surface analysis. CrystEngComm 11:19-32

14. Adonin SA, Gorokh ID, Samsonenko DG, Novikov AS, Korolkov IV, Plyusnin PE et al (2019) Binuclear and polymeric bromobismuthate complexes: Crystal structures and thermal stability. Polyhedron 159:318-322

15. Dhifi M, Thabet S, Harchani A, Haddad A (2019) Synthesis, characterization, Hirshfeld surface analysis and theoretical calculation of new organic-inorganic hybrid material: $\left(\mathrm{C}_{4} \mathrm{H}_{7} \mathrm{~N}_{2}\right)_{6}\left[\mathrm{As}_{2} \mathrm{~W}_{18} \mathrm{O}_{62}\right] \cdot 4 \mathrm{H}_{2} \mathrm{O}$. J Iran Chem Soc 16:777-784

16. Tahiri O, Kassou S, El Mrabet R, Belaaraj A (2019) Synthesis, Hirshfeld surface analysis, optical and electronic properties of the functional hybrid perovskite $\left[\mathrm{NH}_{3}-\left(\mathrm{CH}_{2}\right)_{2}-\mathrm{NH}_{3}\right] \mathrm{CdCl}_{4}$ : a combined experimental and theoretical study. Materials Research Express 6:076301

17. Amamou W, Feki H, Chniba-Boudjada N, Zouari F (2014) Synthesis, crystal structure, vibrational properties and theoretical investigation of ( $\mathrm{N}, \mathrm{N}$-dimethylbenzylammonium) trichlorocadmate (II). J Mol Struct 1059:169-175

18. Rached AB, Maalej W, Guionneau P, Daro N, Mhiri T, Feki H et al (2018) Synthesis, crystal structure, and vibrational and DFT simulation studies of benzylammonium dihydrogen phosphite. J Phys Chem Solids 123:150-156

19. Sajan D, Binoy J, Pradeep B, Krishna KV, Kartha V, Joe IH et al (2004) NIR-FT Raman and infrared spectra and ab initio computations of glycinium oxalate. Spectrochimica Acta Part A: Molecular Biomolecular Spectroscopy 60:173-180

20. Yang B, Mao X, Hong F, Meng W, Tang Y, Xia X et al (2018) Lead-free direct band gap doubleperovskite nanocrystals with bright dual-color emission. J Am Chem Soc 140:17001-17006

21. Ye $Y$, Run $X$, Hai-Tao $X$, Feng $H$, Fei $X$, Lin-Jun $W(2015)$ Nature of the band gap of halide perovskites $\mathrm{ABX}_{3}\left(\mathrm{~A}=\mathrm{CH}_{3} \mathrm{NH}_{3}, \mathrm{Cs} ; \mathrm{B}=\mathrm{Sn}, \mathrm{Pb} ; \mathrm{X}=\mathrm{Cl}, \mathrm{Br}\right.$, I): First-principles calculations. Chinese Physics $\mathrm{B}$. 24:116302

22. Ravi VK, Markad GB, Nag A (2016) Band edge energies and excitonic transition probabilities of colloidal $\mathrm{CsPbX}_{3}(\mathrm{X}=\mathrm{Cl}, \mathrm{Br}, \mathrm{I})$ perovskite nanocrystals. ACS Energy Letters 1:665-671

23. Hu X, Wang J, Mao W, Zheng G, Mo S, Tian N et al (2021) Synthesis, Crystal Structure, Optical Properties and Stability of New Bismuth-Based Organic-Inorganic Compounds $\left(\mathrm{C}_{6} \mathrm{H}_{9} \mathrm{~N}_{2}\right)_{\mathrm{a}} \mathrm{Bi}_{\mathrm{b}} \mathrm{X}_{\mathrm{c}} \mathrm{X}=$ 
Figures

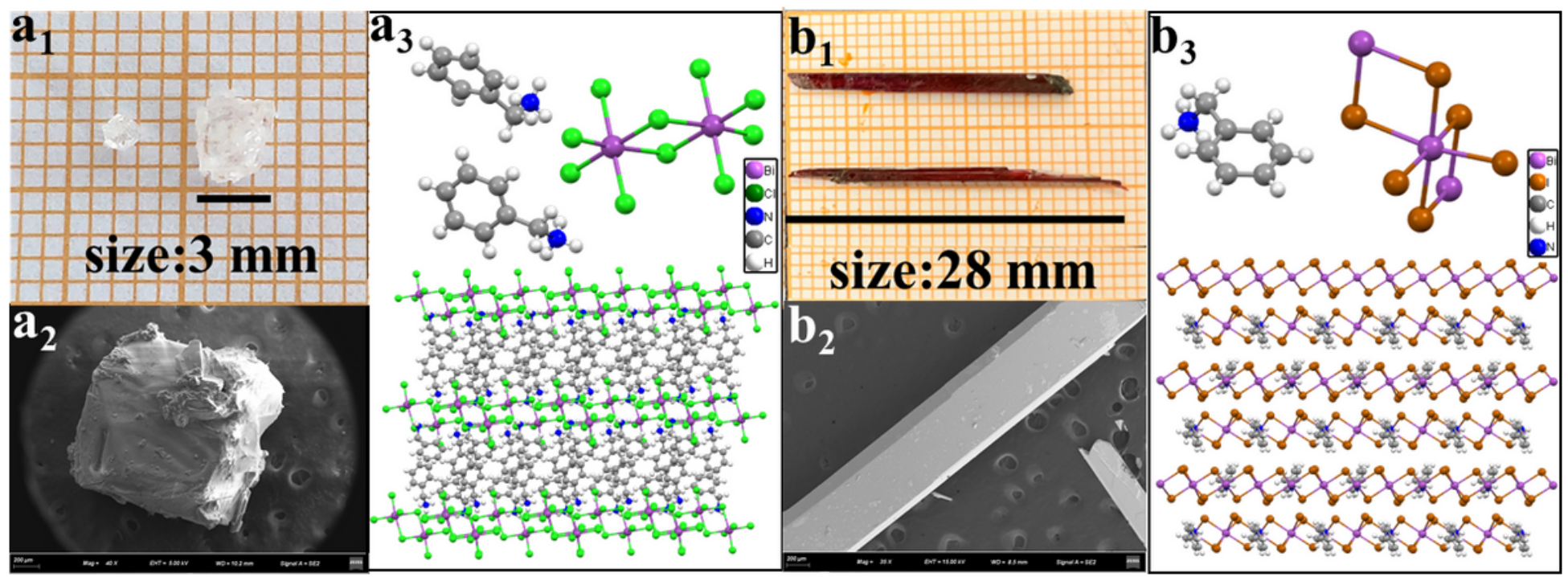

Figure 1

a1-The digital photograph of the $(\mathrm{C} 6 \mathrm{H} 5 \mathrm{CH} 2 \mathrm{NH} 3) 2 \mathrm{BiCl} 5$ single crystal; b1-The digital photograph of the (C6H5CH2NH3)Bil4 single crystal; a2-The SEM image of (C6H5CH2NH3)2BiCl5 single crystal; b2-The SEM image of (C6H5CH2NH3)Bil4 single crystal; a3-The crystal structure of the (C6H5CH2NH3)2BiCl5; b3-The crystal structure of the $(\mathrm{C} 6 \mathrm{H} 5 \mathrm{CH} 2 \mathrm{NH} 3) \mathrm{Bil} 4$
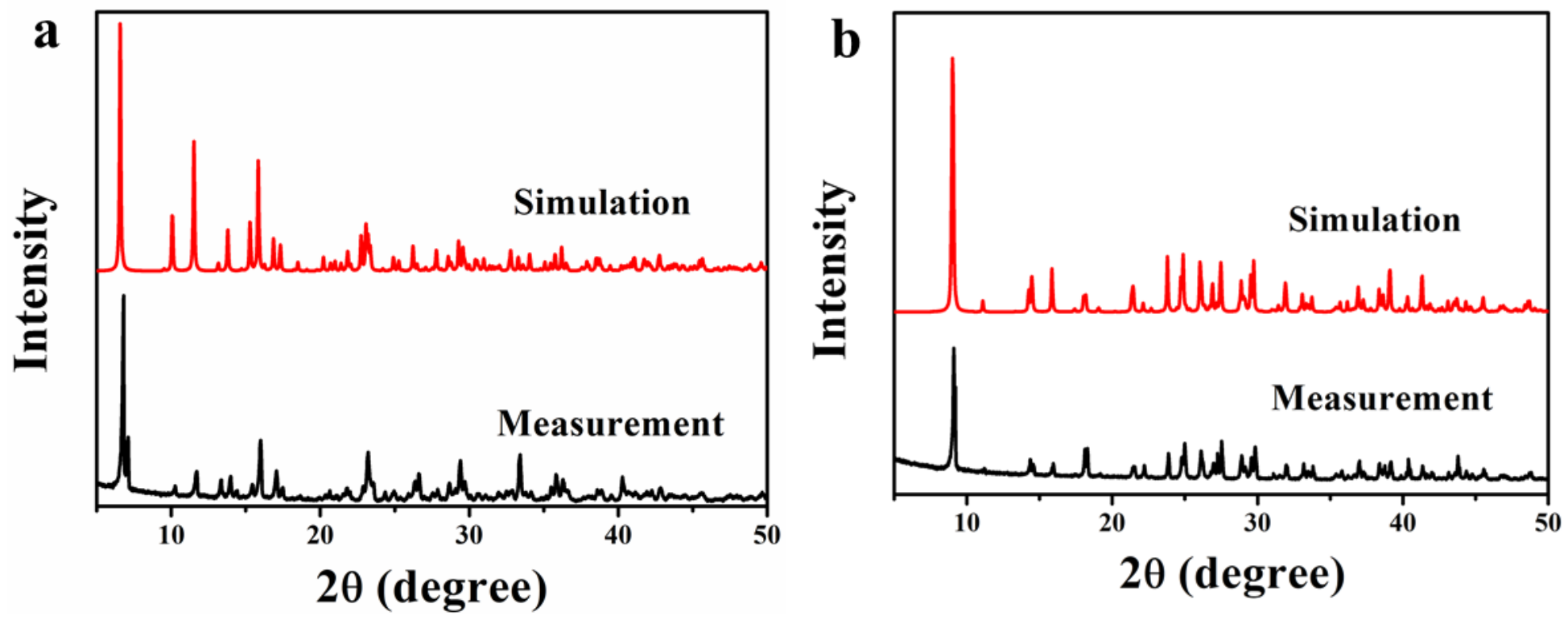

Figure 2

a1-Experimental powder PXRD and simulated PXRD patterns of (C6H8N2)BiCl5; b2-Experimental powder PXRD and simulated PXRD patterns of $(\mathrm{C} 6 \mathrm{H} 5 \mathrm{CH} 2 \mathrm{NH} 3)$ Bil4 


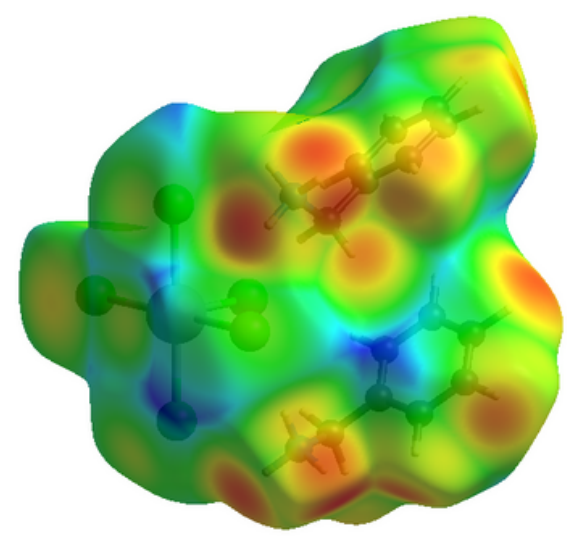

$\mathbf{a}_{1}$

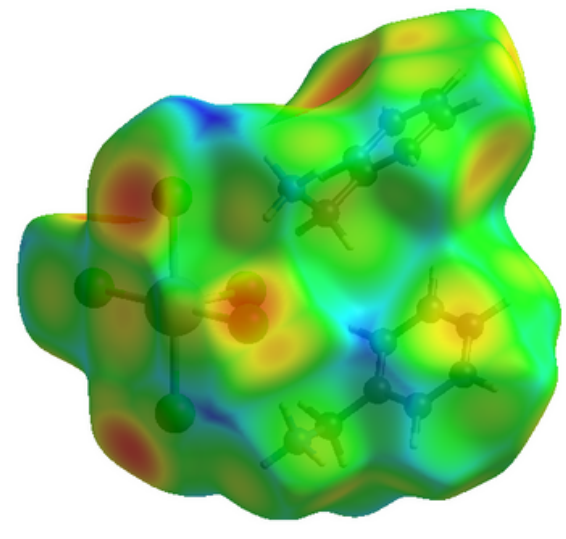

$\mathbf{a}_{2}$

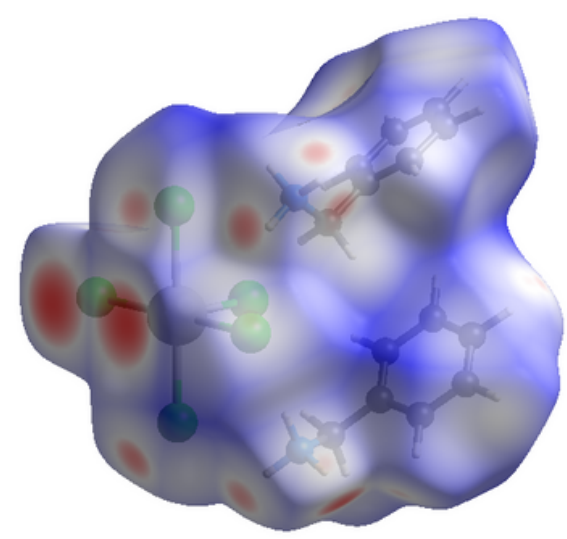

$\mathbf{a}_{3}$

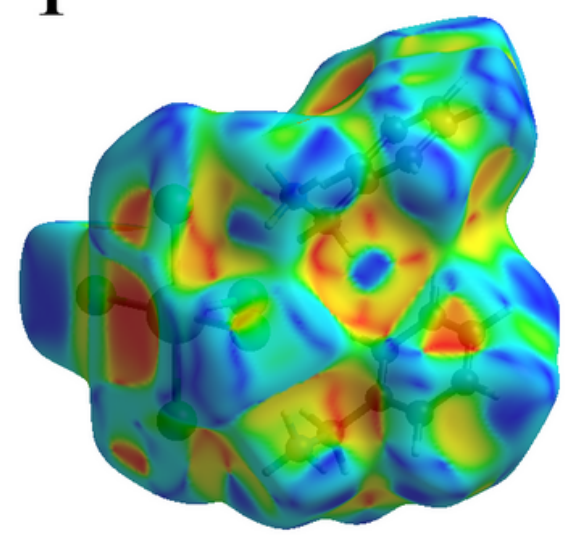

$\mathbf{a}_{4}$

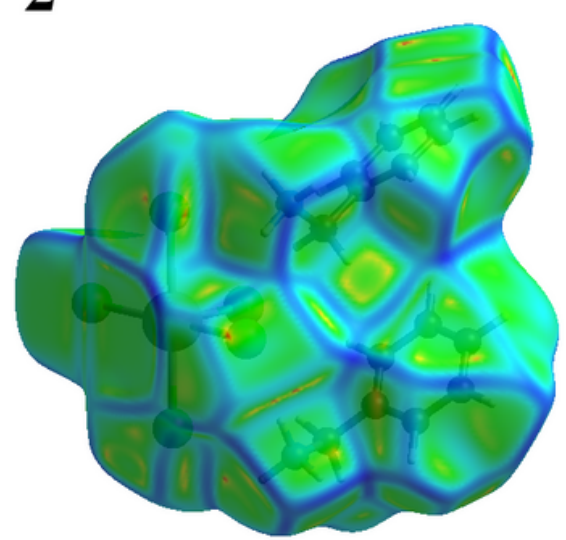

$\mathbf{a}_{5}$

Figure 3

The Hirshfeld surface for (C6H5CH2NH3)2BiCl5 mapped with 'di', 'de', 'dnorm', shape index and curvedness curves 


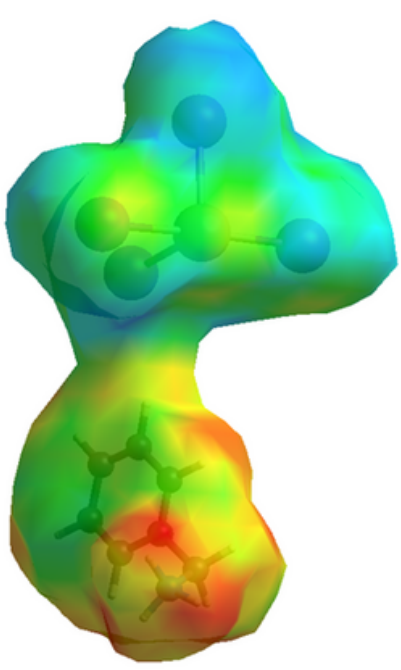

$\mathbf{a}_{1}$

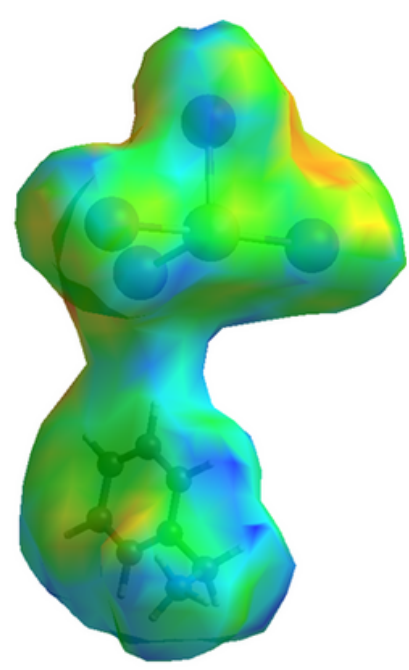

$a_{2}$

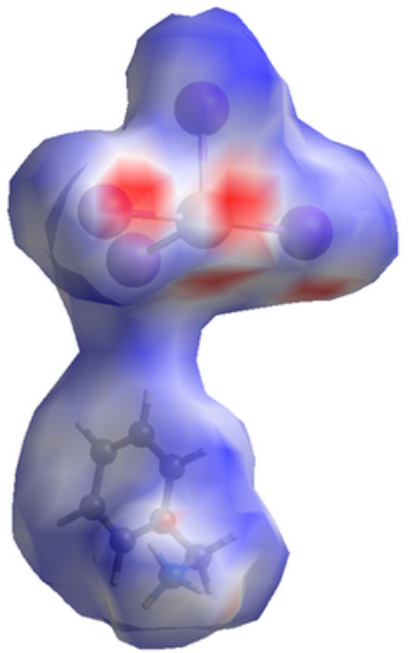

$\boldsymbol{a}_{3}$

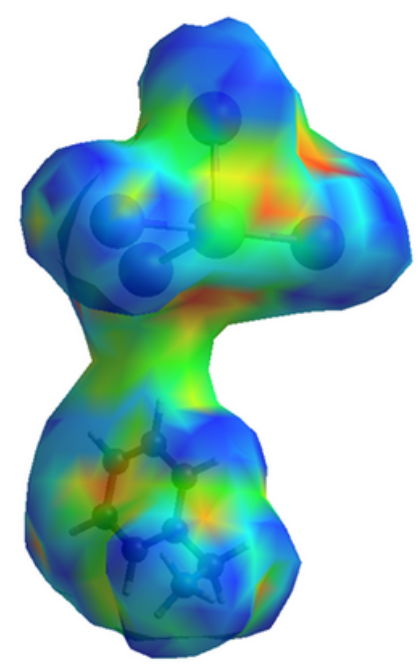

$a_{4}$

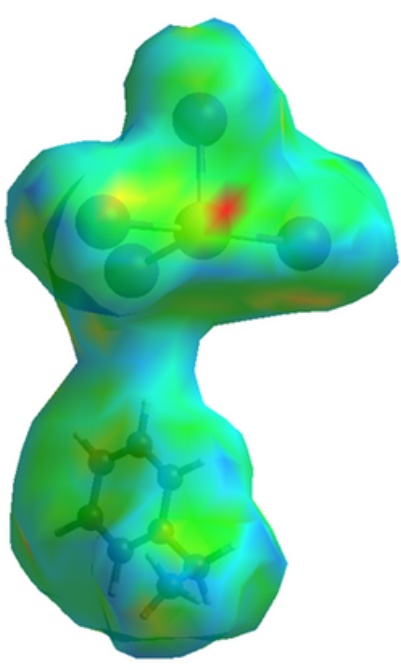

$\mathbf{a}_{5}$

Figure 4

The Hirshfeld surface for (C6H5CH2NH3)Bil4 mapped with 'di', 'de', 'dnorm', shape index and curvedness curves 

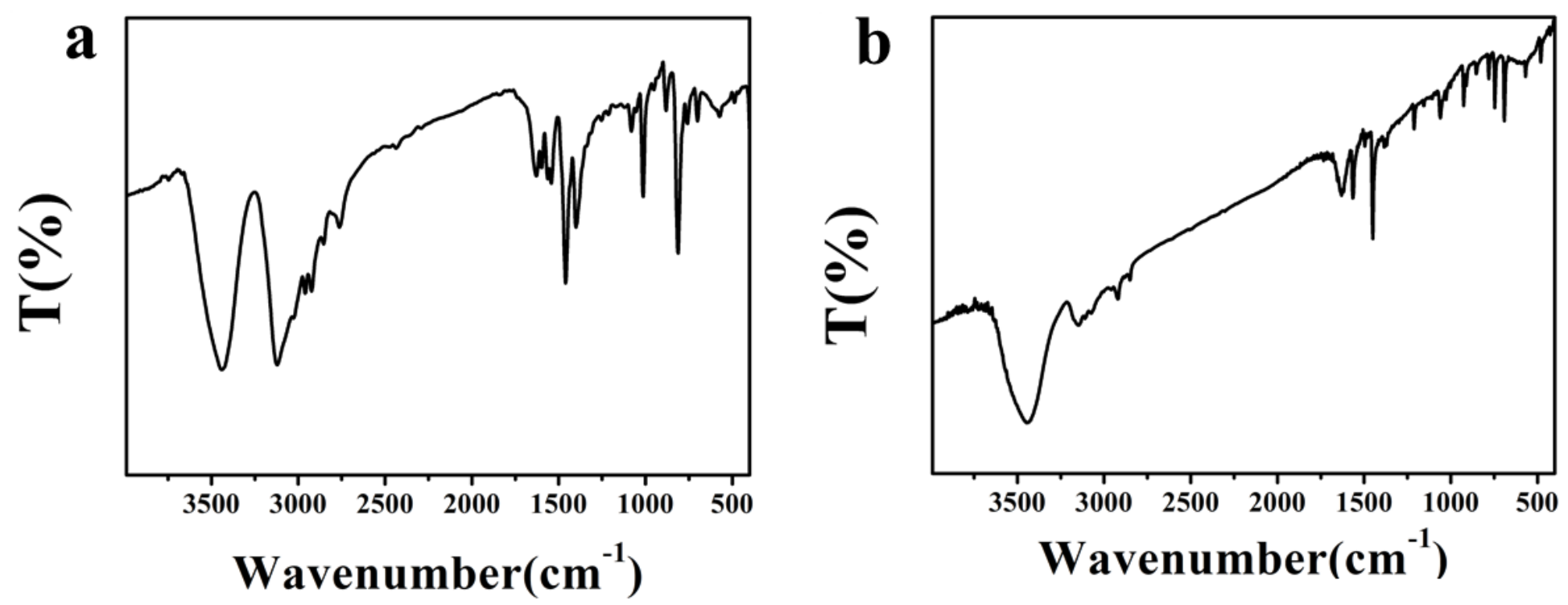

Figure 5

a-IR spectrum of $(\mathrm{C} 6 \mathrm{H} 5 \mathrm{CH} 2 \mathrm{NH} 3) 2 \mathrm{BiCl} 5 ; \mathrm{b}-\mathrm{IR}$ spectrum of $(\mathrm{C} 6 \mathrm{H} 5 \mathrm{CH} 2 \mathrm{NH} 3) \mathrm{Bil} 4$
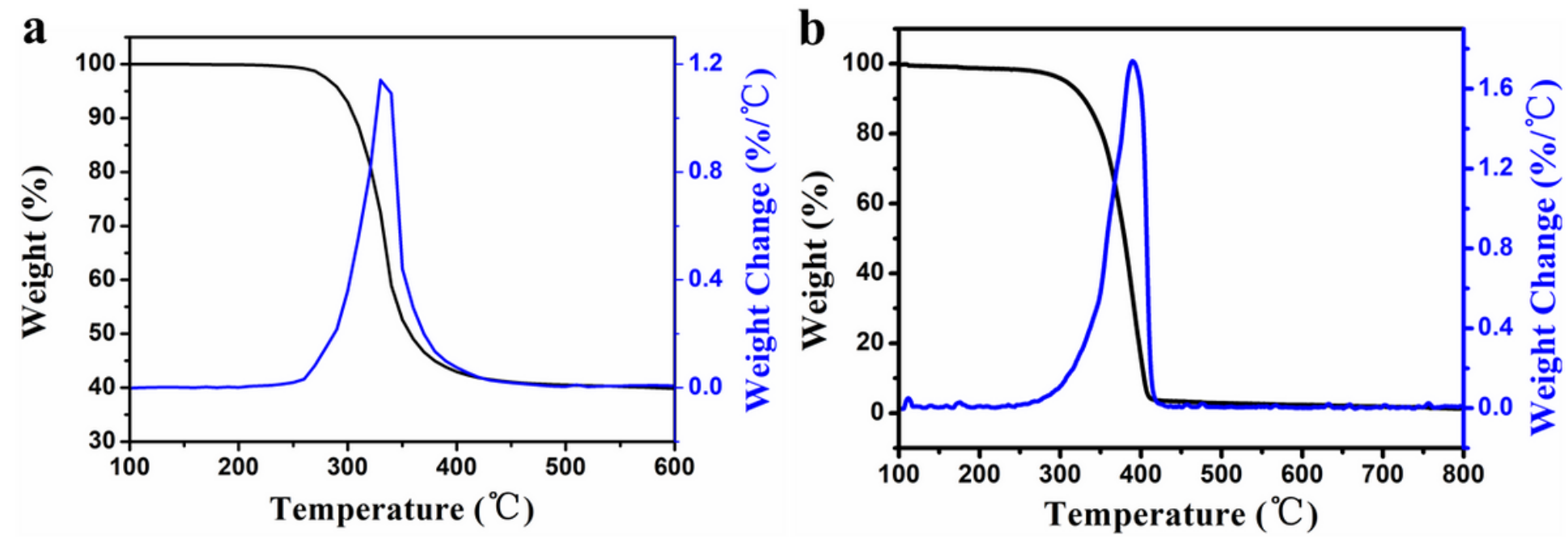

Figure 6

a-TGA curve of (C6H5CH2NH3)2BiCl5; b-TGA curve of (C6H5CH2NH3)Bil4 

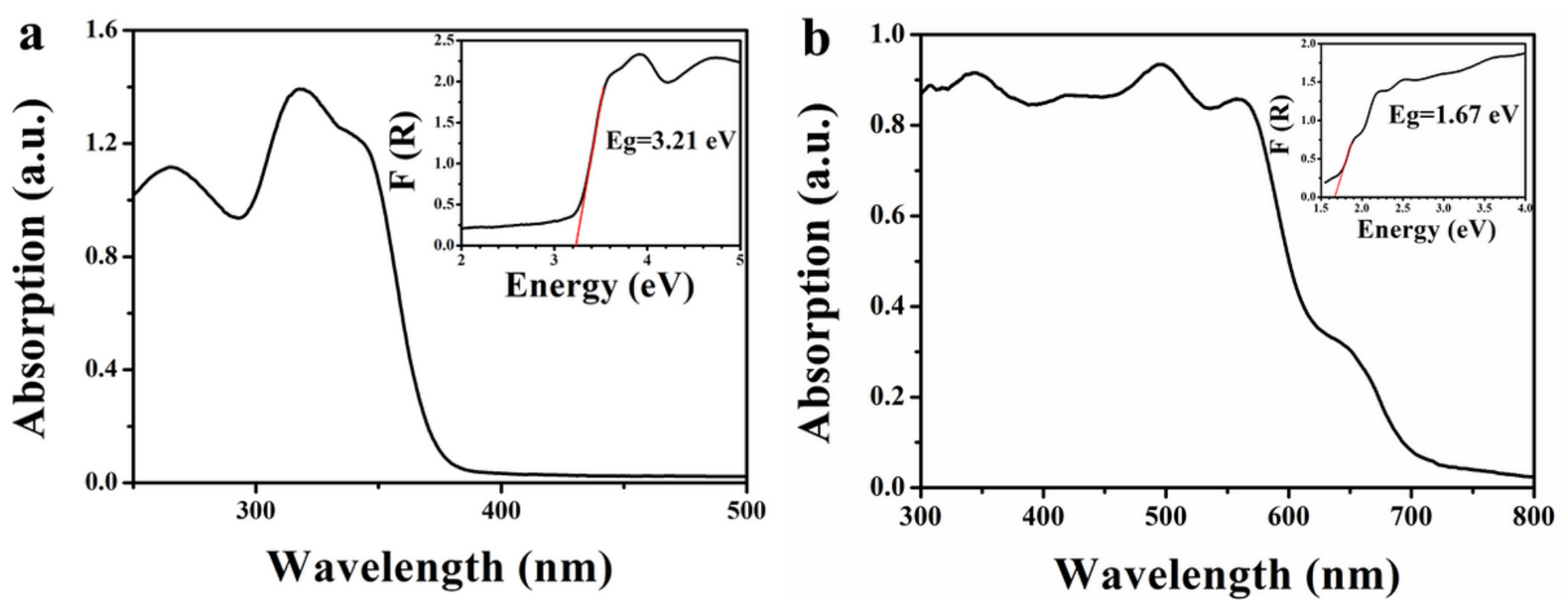

Figure 7

a-UV-vis diffuse reflectance spectroscopy plots of (C6H5CH2NH3)2BiCl5; b-UV-vis diffuse reflectance spectroscopy plots of $(\mathrm{C} 6 \mathrm{H} 5 \mathrm{CH} 2 \mathrm{NH} 3)$ Bil4

\section{Supplementary Files}

This is a list of supplementary files associated with this preprint. Click to download.

- Supportinglnformation1.docx 